\title{
Certain Properties of Needle Punched Nonwoven Fabrics Made from Silk and Wool Fibers
}

\author{
Rajkumar Govindaraju* and Srinivasan Jagannathan \\ Department of Fashion Technology, Kumaraguru College of Technology, India
}

*Corresponding author: Rajkumar Govindaraju, Department of Fashion Technology, Kumaraguru College of Technology, Coimbator-641 049, Tamil Nadu, India

Submission: 監 October 11, 2017; Published: 監February 08, 2018

\begin{abstract}
This research work describes the development of needle punched non woven fabrics from silk fibre waste and wool fibers. The nonwoven fabrics are developed using silk and wool fibers at five different proportions namely $100 \%$ silk, $70 / 30$ silk/wool, 50/50 silk/wool, 30/70 silk/wool, $100 \%$ wool using needle punching technique. The influence of blend proportions of the silk and wool fibers on the comfort properties of the nonwoven fabrics such as air permeability, wick ability and thermal conductivity were studied. It is found from the results that the blend proportion has a significant effect on the comfort properties of the non woven fabrics. The $100 \%$ wool non-woven fabric has shown higher air permeability, wick ability and lower thermal conductivity. The $100 \%$ silk non-woven fabric has shown lower bursting strength.
\end{abstract}

Keywords: Silk waste; Wool; Needle punching; Thermal conductivity; Wick ability

\section{Introduction}

Recycling is an important task in today's scenario to reduce land filling and raw material consumption which also helps in the effective utilization of the resources. Huge amount of waste is occurred in textile industries such as fibers, yarns and fabrics while converting one form of raw material into other form. Recently, these wastes are utilized for the development of non woven fabrics and composite materials which has high potential to utilize it in civil and automobile industries as insulating materials.

The fibrous assembly developed from recycled polyester fibers has been used as acoustic materials in construction industries [1]. Sun flower stalk, textile waste and stubble fibers are used for the development of environmental friendly thermal insulating materials [2]. Wool fibers and recycled polyester fibers have been used for the development thermal and sound insulation material for building industry applications [3]. An increase in the tensile strength and toughness was observed by reinforcing the mortar with recycled nylon fibers [4]. Recycled wool based non woven material developed as a sorbent in an oil spill cleanup has shown high oil sorption capacity when compared commercially available synthetic based materials [5].

Silk and wool are natural protein fibers. Huge amount of silk and wool fibre waste is occured while processing the silk and wool fibers in textile industries. Only very few literatures are available on the utilization of recycled silk and wool fibers [6-8]. Therefore, the main objective of the present work is to utilize the silk and wool fibre wastes for the development of non woven fabrics using needle punching technique. Further, the influence of blend proportions of silk and wool fibers on the comfort properties of the non woven fabrics are also studied.

\section{Materials and Methods}

\section{Materials}

Reclaimed silk fibers from shuttle-less loom silk selvedge waste and wool fibers were used for the development of non woven fabrics in this work. The silk selvedge waste was obtained from Ethnic Fashions, Bengaluru. The wool fibers were procured from Tirupati fibers, Panipat. The staple length, fineness and strength of the fibers were measured as per BISFA'1998, ASTM D 1448 and ASTM D-3822-07 standards respectively. The physical properties of the silk and wool fibers are given in Table 1.

Table 1: Physical properties of the fibers.

\begin{tabular}{|c|c|c|c|c|}
\hline Fiber & $\begin{array}{c}\text { Staple Length } \\
\text { (mm) }\end{array}$ & $\begin{array}{c}\text { Fineness } \\
\text { (Tex) }\end{array}$ & $\begin{array}{c}\text { Strength } \\
\text { (G/Den) }\end{array}$ & $\begin{array}{c}\text { Elongation } \\
\text { (\%) }\end{array}$ \\
\hline Silk* & $75 \pm 10$ & 0.12 & $4.5 \pm 7$ & $13.50 \pm 12$ \\
\hline Wool & $45 \pm 6$ & 1.54 & $1.5 \pm 6$ & $26.30 \pm 9$ \\
\hline
\end{tabular}

*Retrieved silk fibers from shuttle -less loom silk selvedge waste

\section{Methods}

Opening of silk selvedge waste: The silk selvedge waste obtained from the shuttle-less loom weaving mills was cleaned manually to remove non silk materials present in the silk selvedge waste such as cotton leno threads. The cleaned silk threads were opened into fibrous form using hard waste opening machine. The photographic images of silk selvedge waste and cleaned silk threads are shown in Figure $1 \& 2$. 

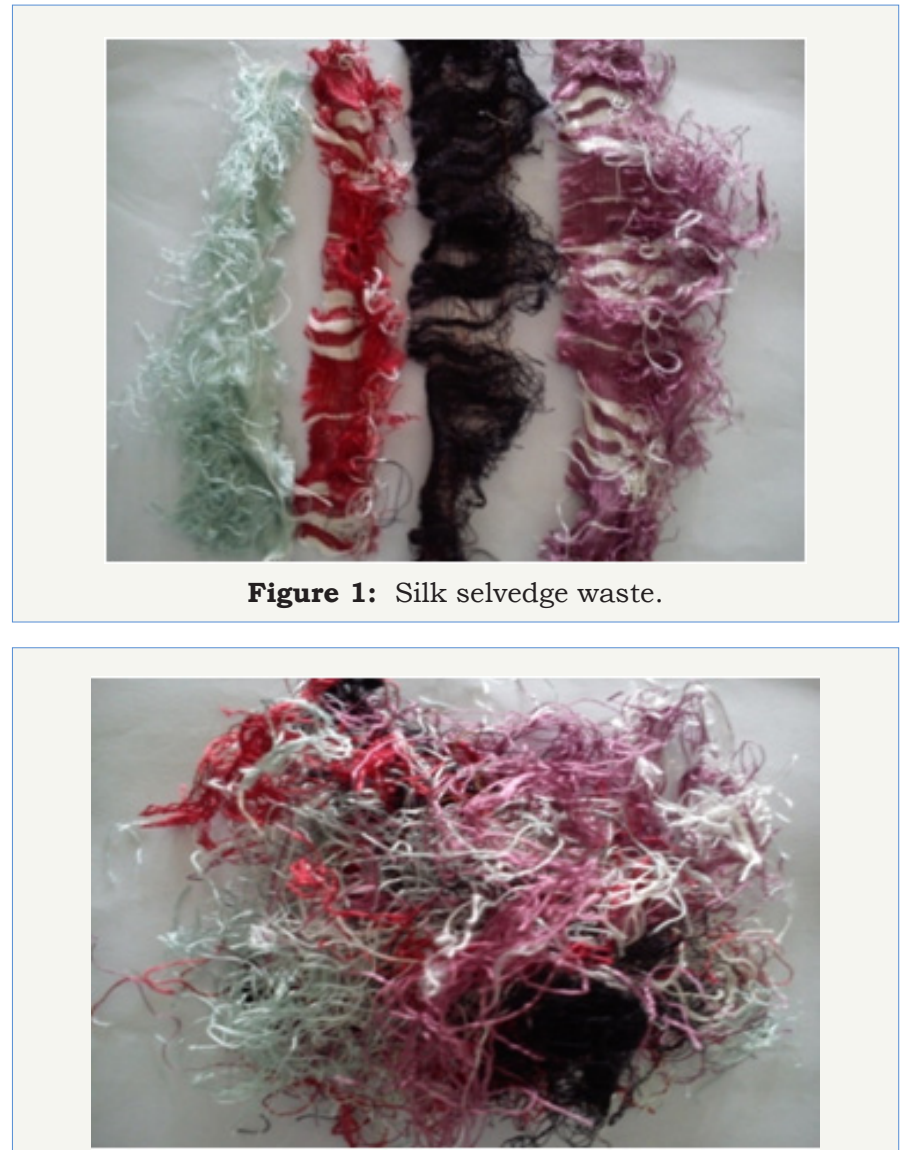

Figure 1: Silk selvedge waste.

Scouring of wool: Wool fiber was scoured using sodium carbonate and soap with material to liquor (m:l) ratio of $1: 10$ and the treatment time and temperature were $45 \mathrm{~min}$ and $50{ }^{\circ} \mathrm{C}$ respectively. The treated wood fibers from the hot alkali bath were then cleaned using water and dried.

Blending: Silk and wool fibers were blended with different proportions using a lab model blending machine. The different proportions of silk and wool fibers used for the fabrication of non woven fabrics are given in Table 2.

Table 2: Blend proportions of silk and wool fibers.

\begin{tabular}{|c|c|}
\hline Sl. No & Blend Proportion (Silk/Wool) \\
\hline 1 & $100: 00$ \\
\hline 2 & $70: 30$ \\
\hline 3 & $50: 50$ \\
\hline 4 & $30: 70$ \\
\hline 5 & $0: 100$ \\
\hline
\end{tabular}

Web formation: The blended silk and wool fibers were fed into carding machine to obtain carded web. During carding, the fiber blend was further opened and individual fibers were combed to be relatively parallel. The fiber blend was carded four times to enhance web uniformity. Four webs are superimposed one above the other to obtain required thickness in the final non woven fabric.

Needle Punching: The needle punching was carried out in Dilo, German made needle punching machine. The non woven fabrics were developed at 300 punches $/ \mathrm{cm}^{2}$ at a speed of $257 \mathrm{cycles} / \mathrm{min}$ and at $11 \mathrm{~mm}$ needle penetration depth using barbed needle. The Figure 3 depicts the needle punching of silk and wool fibre web.

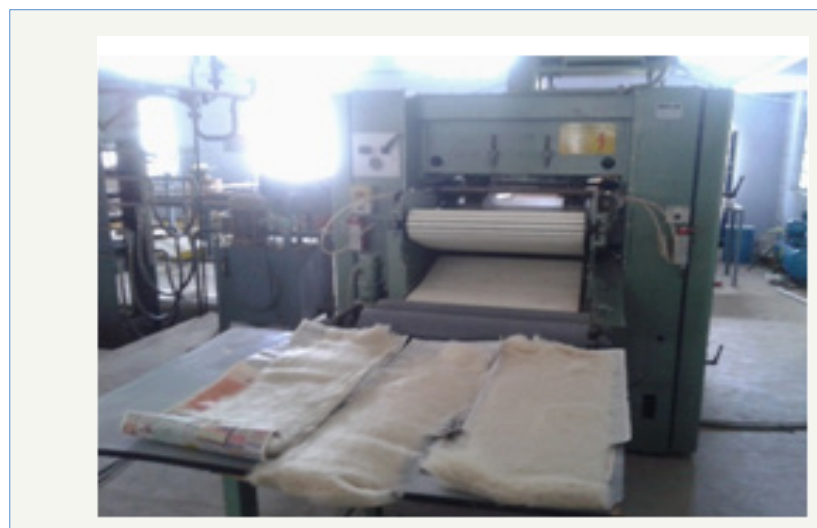

Figure 3: Needle punching of silk and wool fiber web.

\section{Testing}

The physical properties of the non woven fabric such as thickness (ASTM D 1777) and grams per square meter were determined. The comfort properties of the non woven fabrics such as air permeability, wick ability and thermal conductivity were also determined. The air permeability of fabrics was determined according to ASTM D737 using MAG Solvics air permeability tester. The rate of air permeability was measured using the following equation

$$
\text { Air Permeability }[\mathrm{R}]=\frac{r}{a} \mathrm{~cm} / \mathrm{sec}
$$

Where, $\mathrm{r}=$ mean rate of flow of air in $\mathrm{cm}^{3} / \mathrm{s}$, a=area $\mathrm{cm}^{2}$ of fabric under test.

The thermal conductivity was determined using Lees disc method using the following equation

$$
K=\frac{M s d(r+2 l)(d \theta / d t)}{\pi r^{2}(2 r+2 l)(\theta 1-\theta 2)} \text { watt/meter/Kelvin }
$$

The wicking height of the fabrics was determined as per DIN 53924 using strip test method. A fabric strip of $200 \mathrm{~mm}$ x $25 \mathrm{~mm}$ was suspended vertically with $30 \mathrm{~mm}$ of its lower end immersed in distilled water. The height reached by the water in the fabric was noted with respect to time at regular intervals.

\section{Results and Discussion}

Table 3: Physical properties non woven web.

\begin{tabular}{|c|c|c|c|}
\hline $\begin{array}{c}\text { Sample } \\
\text { Code }\end{array}$ & $\begin{array}{c}\text { Blend Ratio (Silk/ } \\
\text { Wool) }\end{array}$ & $\begin{array}{c}\text { Thickness } \\
\text { (mm) }\end{array}$ & GSM \\
\hline SW1 & $100: 0$ & 1.16 & 140 \\
\hline SW2 & $70: 30$ & 1.22 & 172 \\
\hline SW3 & $50: 50$ & 2.10 & 194 \\
\hline SW4 & $30: 70$ & 2.78 & 231 \\
\hline SW5 & $0: 100$ & 3.76 & 295 \\
\hline
\end{tabular}


The physical properties of the non woven fabrics are given in Table 3. The variation in the thickness and fabric weight (GSM) of the nonwoven fabrics is due to the variation in the physical properties of silk and wool fibers.

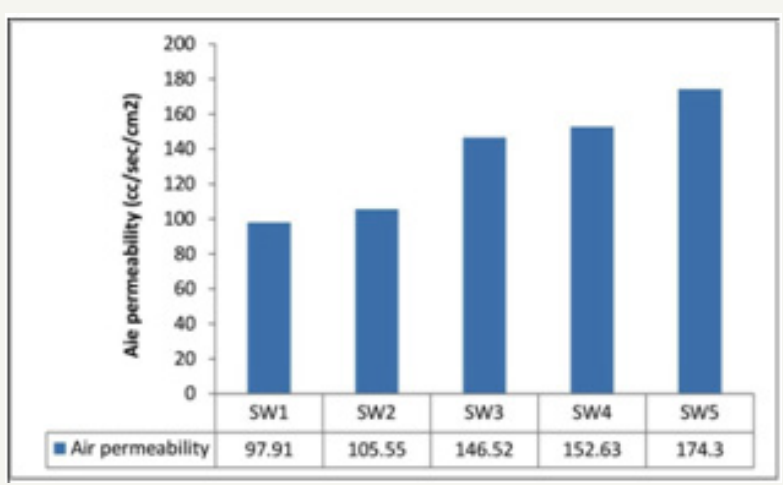

Figure 4: Air permeability of non woven fabrics.

The air permeability of the non woven fabrics is given in Figure 4. The results indicated that $100 \%$ wool non woven fabric has shown highest air permeability values. The $100 \%$ silk non woven fabric has shown lowest value of $97.91 \mathrm{cc} / \mathrm{sec} / \mathrm{cm}^{2}$. Air permeability is an important property of textile materials which influence the flow of vapour from the human body to the environment and the flow of fresh air to the body [9]. An increase in the air permeability was observed when wool fibre content increases in the blend. In hybrid nonwovens, the $30 / 70$ silk/wool non-woven fabric has shown higher air permeability.

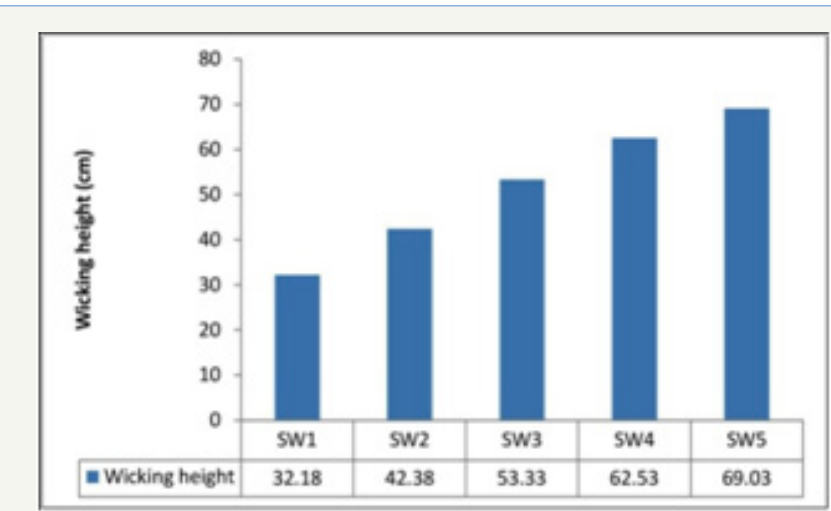

Figure 5: Wicking height of non woven fabrics.

Figure 5 depicts the wicking height of silk, silk/wool hybrid and wool needle punched nonwoven fabrics. It is found that the wool nonwoven has given higher wicking height than the silk nonwoven fabric. In hybrid nonwovens, the 30/70 silk/wool non-woven fabric has shown higher wicking height. This is due to the higher moisture absorption of wool fibers compared to silk fibers.

Thermal conductivity is an intrinsic property of a material that indicates its ability to conduct heat. It is the flux of heat (energy per unit area per unit time) divided by the temperature gradient. It is observed from Figure 6 that the thermal conductivity reduces with increase in wool fibre content in the hybrid fibre non woven fabric. Further the thermal conductivity of the wool non woven fabric is lower than the silk non woven fabric. This may be due to the lowest thermal conductivity value of wool fibers than silk fibers.

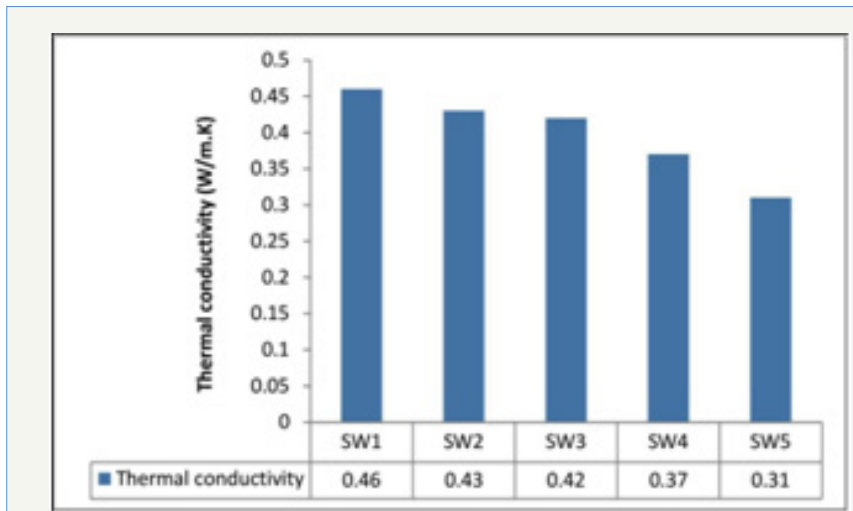

Figure 6: Thermal conductivity of non woven fabrics.

The bursting strength of the $100 \%$ wool non woven fabric was higher when compared to silk and hybrid non woven fabrics. This is due to the felting property of the wool fibre in needle punching. The $100 \%$ silk non woven fabric has given lower bursting strength. It is also observed that the bursting strength is increased with increase in wool fibre content in the hybrid non woven fabrics. Figure 7 shows the bursting strength of the non woven fabrics.

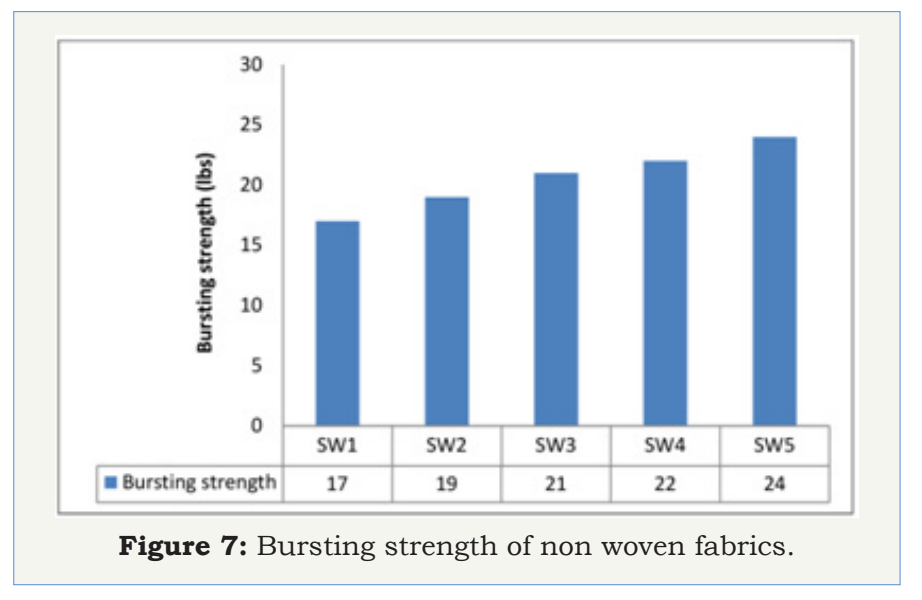

\section{Conclusion}

The comfort properties of needle punched non woven fabrics made from recycled silk and wool fibers in different blend ratios (100\% silk, 70/30 silk/wool, 50/50 silk/wool, 30/70 silk/wool and $100 \%$ wool) were investigated. An increase in air permeability and wicking height was found with increase in wool fibre content in the non woven fabrics. It was also observed that the thermal conductivity and bursting strength decreases with increase in wool fibre content in the non woven fabrics. The $100 \%$ wool non woven fabric has given lower thermal conductivity. The nonwoven fabrics developed in this work can be used as a thermal interlining material in winter garments.

\section{References}

1. Lee Y, Joo C (2003) Sound absorption properties of recycled polyester fibrous assembly absorbers. AUTEX Research Journal 3(2): 78-84.

2. Binici H, Eken M, Dolaz M, Aksogan O, Kara M (2014) An environmentally friendly thermal insulation material from sunflower stalk, textile waste and stubble fibers. Construction and Building Materials 51:24-33. 
3. Patnaik A, Mvubu M, Muniyasamy S, Botha A, Anandjiwala RD (2015) Thermal and sound insulation materials from waste wool and recycled polyester fibers and their biodegradation studies. Energy and Buildings 92: 161-169.

4. Spadea S, Farina I, Carrafiello A, Fraternali F (2015) Recycled nylon fibers as cement mortar reinforcement. Construction and Building Materials 80: 200-209.

5. Radetić MM, Jocić DM, Jovančić PM, Petrović ZL, Thomas HF (2003) Recycled wool-based nonwoven material as an oil sorbent. Environmental science \& technology 37(5): 1008-1012.

6. Rajkumar G, Srinivasan J, Suvitha L (2013) Development of novel silk/wool hybrid fibre polypropylene composites. Iranian Polymer Journal 22(4): 277-284.
7. Rajkumar G, Srinivasan J, Suvitha L (2015) Natural protein fiber hybrid composites: Effects of fiber content and fiber orientation on mechanical, thermal conductivity and water absorption properties. Journal of Industrial Textiles 44(5): 709-724.

8. Govindaraju R, Jagannathan S, Chinnasamy M, Kandhavadivu P (2014) Optimization of Process Parameters for Fabrication of Wool FiberReinforced Polypropylene Composites with Respect to Mechanical Properties. Journal of Engineered Fabrics \& Fibers (JEFF) 9(3): 1-8.

9. Chidambaram P, Govindan R, Venkatraman KC (2012) Study of thermal comfort properties of cotton/regenerated bamboo knitted fabrics. African Journal of Basic \& Applied Sciences 4(2): 60-66.

\section{Your subsequent submission with Crimson Publishers}

\section{will attain the below benefits}

- High-level peer review and editorial services

- Freely accessible online immediately upon publication

- Authors retain the copyright to their work

- Licensing it under a Creative Commons license

- Visibility through different online platforms

- Global attainment for your research

- Article availability in different formats (Pdf, E-pub, Full Text)

- Endless customer service

- Reasonable Membership services

- Reprints availability upon request

- One step article tracking system 